\title{
Challenges and Perspectives for Rural Development
}

\author{
Natalia Ovchinnikova ${ }^{1 *}$ and Tatyana Vodolazskaya ${ }^{1}$ \\ ${ }^{1}$ Don State Technical University, 1, Gagarina sq., 344003, Rostov-on-Don, Russia
}

\begin{abstract}
The development of rural areas which are currently in a state of crisis can be understood as the implementation of federal programs for sustainable development of rural areas with the purpose to eliminate this crisis situation. In our country their implementation began as early as 2003 . The stable development of rural community ensures the fulfillment of its national economic functions, maintains ecological balance in the biosphere which are the indicators that stipulate a concept of sustainable development of rural areas. This article deals with the problems of establishing the boundaries of settlements through systematization of the results of federal target programs for the sustainable development of rural areas, taking into account natural, climatic and economic conditions of the country's territories.
\end{abstract}

\section{Introduction}

The procedure for establishing or changing the boundaries of residential settlements and their subsequent entry in the Unified State Register of Immovable Property is inseparably linked to its subsequent sustainable development and at the same time solves the problem of providing a constituent entity of the Russian Federation with accurate information about the borders with neighboring constituent entities of the Russian Federation and up-to-date large-scale cartographic materials.

Back in 2018, the Deputy Head of the regional Rosreestr department reported that only 60 out of almost 3,000 settlements in the Rostov region had exact boundaries as of April 2018.

He asked the regional government and local authorities to hurry up with the issue of bringing the boundaries in order, as experience had shown that it would take about six months to establish the boundaries of an average-sized settlement $[1,2]$.

\section{Materials and methods}

The issue of rectifying settlements boundary lines is of highest relevance at the moment due to the fact that our region is soon to complete the updating of internal administrative boundaries. These works are largely related to the interests of the population. Thus,

* Corresponding author: donong160875@yandex.ru 
according to the Head of the Ministry of Construction of the Rostov Region, "From January 1,2021 , in the absence of information on the boundaries of settlements and territorial zones in Rosreestr, municipalities will be prohibited from issuing permits for housing construction." He also said that in the Rostov Region the borders of 2,291 settlements must be defined and information on more than 60,000 territorial areas must be entered into UGRN during the year 2020 [3] .

To solve this problem in agriculture, a foundation is needed that would provide a synergy of ecology, economy and society through interconnection of environmental processes, agricultural production and living environment of the rural population. The land and property complex of rural areas is to be deemed as such a foundation[4] .

\section{Results}

The land-property complex is understood as total land resources, a spatial basis for life and economic activity of rural population, and a real estate object with its various forms of ownership and as an element of market relations.

On the other hand, the land and property complex of rural areas represents a basis for agricultural activities and a frame of agro-industrial complex in the countryside. Therefore, in our opinion, in order to ensure rational use of land resources and labor base of rural areas nowadays, an effective system of management of the land and property complex of rural areas should be created $[5,6]$.

Such a management system is understood as a balance between economic, environmental and social spheres. That is, creation of comfortable conditions for production, protection and restoration of natural resources of land and property complex, and protection of rights and interests of the subjects of land and property relations [7].

When viewed in a broader sense, sustainable development implies meeting the needs of humanity at all levels without prejudice to future generations. The concept of sustainable development is far from new. It has been around and evolving for quite a long time. The idea of sustainable development is the result of a transition from ecologization of scientific knowledge and socio-economic development to practical actions, which started intensively in the $70 \mathrm{~s}$ of the 20 th century. At that time, society was faced with the issue of environmental pollution and depletion (limitation) of natural resources [8] .

Scientists have been engaged in researching problems and finding solutions. After all, natural environment is a basis of all life processes in society which take place in the political, economic, social, environmental, production, and other spheres. Awareness of the threat of approaching crisis of natural resources led to the creation of international nongovernmental scientific organizations for the study of global processes on Earth, such as the International Federation of Institutes for Advanced Studies, the Club of Rome, the International Institute for Applied Systems Analysis, and in the USSR - the All-Union Institute for Systems Research. All above mentioned contributed to the creation of the idea of sustainable development. The term "sustainable development" in its classical content was formulated in 1987 in the report entitled "Our Common Future", presented by the International Commission on Environment and Development [9].

Thus, sustainable development, in general, is a development that meets the needs of the present without jeopardizing the ability of future generations to meet their needs $[10,11]$.

\subsection{Concept of sustainable development}

Each country slightly modifies the idea of sustainable development depending on a historically established lifestyle of its society. In the Russian Federation, the term of sustainable development was previously enshrined at the statutory level meaning 
"Harmonious development of production, social sphere, population and natural environment". Nowadays, the concept of sustainable development is contained in legal acts of different levels. And it is related to construction, territorial development, development of agricultural production, economy, etc [12] .

In today's world, a three-pronged concept of sustainable development is the most relevant [13] .

The concept of sustainable development must necessarily include three components: economic, environmental and social. In other words, an essence of the concept of sustainable development is interaction of these spheres so that with each future generation, quality of life of people would increase, environment would be preserved or improved, and movement along the path of social progress would be realized, taking into account the needs of each individual. In other words, there must be a dynamic balance of all spheres and levels of human activity. In our country, measures are being actively implemented to achieve 17 goals, which correspond to 169 specific targets of 2030 Agenda for Sustainable Development, adopted by the leaders of the United Nations Member States in 2015.

The main goal of the Russian Federation for this period is to ensure the well-being of the country's population by creating and maintaining balance of economic, social and environmental efforts. As a result of monitoring the achievement of sustainable development goals in our country, the first statistical yearbook "Sustainable Development Goals in the Russian Federation" has been prepared by the Federal State Statistics Service with the participation of Russian ministries and agencies. The purpose of this publication is to show current state and progress of sustainable development in our country, to compare them with other countries in order to better understand where we are now, what we have achieved and where we need to make additional efforts [6]. There is still quite a lot of work to be done for achieving these objectives, as not all of the indicators presented in this yearbook are positive.

\subsection{Chronology of sustainable rural development}

Since 2003, many programs have been implemented at different levels of government in Russia. Chronology of Sustainable Rural Development in the Russian Federation is shown on Figure 1 below.

Besides, there are many programs at regional or regional level aimed at improving the life conditions of rural settlements in specific areas.

Programs for sustainable development activities are financed from the federal budget, budgets of subjects of the Russian Federation, and non-budgetary sources. All these programs have been completed, stopped, continued, and interconnected with each other.

Analysis of the results of implementation of programs aimed at massive improvement of the socio-economic state of the village implies that, despite demonstrating good indicators (see Fig. 1), they have not brought expected changes, since all this has been carried out over a fairly long period time, but demographic situation in rural areas has not improved lately.

Therefore, as of today, access to basic social benefits for the rural population remains very low[14]. 
Federal Target Program "Rural Social Development"

Subprogram of State Program for Development of Agriculture and Regulation of Agricultural Commodity Markets "Sustainable Rural Development"

$2013-2020$

Departmental Target Program "Sustainable Rural Development"

$2019-2020$
2003 State Program for Development of Agriculture and Regulation of Agricultural Commodity Markets

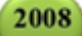

$2008-2012$

Concept of Long-Term Social and Economic Development of the Russian Federation for the period up to 2020

$2008-2020$

Concept of Sustainable Rural Development of the Russian Federation for the period up to 2020

$2010-2020$

Departmental Target Program "Development of Family Stock Farming"

2012

2012 - 2014

Departmental Target Program "Support for Beginning Farmers"

$2012-2017$

Strategy for Sustainable Development of Rural Areas up to 2030 $2015-2030$

Fig. 1 Chronology of Sustainable Rural Development in the Russian Federation.

\section{Discussion}

\subsection{Results of Federal Target Programs for Sustainable Rural Development}

Nowadays, Federal Target Programs are a basis of the organizational and economic mechanism aimed at solving the problems of comprehensive development of rural areas. Sustainable development of rural areas can be ensured only with the sustainable development of rural economy. The land and property complex of rural territories is the economic framework of the domestic management of land use.

Results of Federal Target Programs for sustainable rural development for the period of 2003-2019 are shown on Figure 2. 
The goals of sustainable development of rural areas cannot be achieved without improving a demographic situation and, consequently, labour resource base of agricultural economy. It can be said that population dynamics acts as an indicator of sustainable development of rural areas in Russia.

Creation of the conditions for sustainable development of rural areas is one of the most important strategic goals of national policy to ensure the efficient use of available potential of the country's economy [15].

When implementing sustainable rural development programs, it is necessary to take into account not only universal, but also the ethnic peculiarities of the rural population of our country, natural-climatic and economic conditions resulting from spatial-territorial specificity. The principle of peculiarities of natural-climatic and economic conditions of the country's territories should be taken into account as a basis.

\section{Overall results of Federal Target Programs aimed at rural development}

\begin{abstract}
22 million square meters of housing were built, including more than 8 million square meters for young families and young specialists.
\end{abstract}

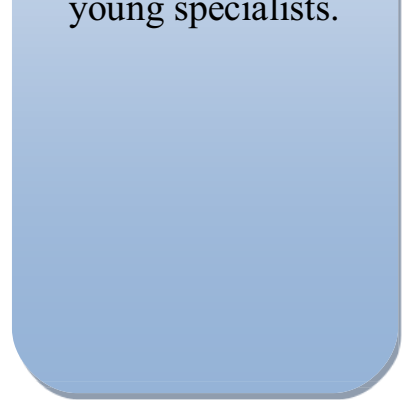

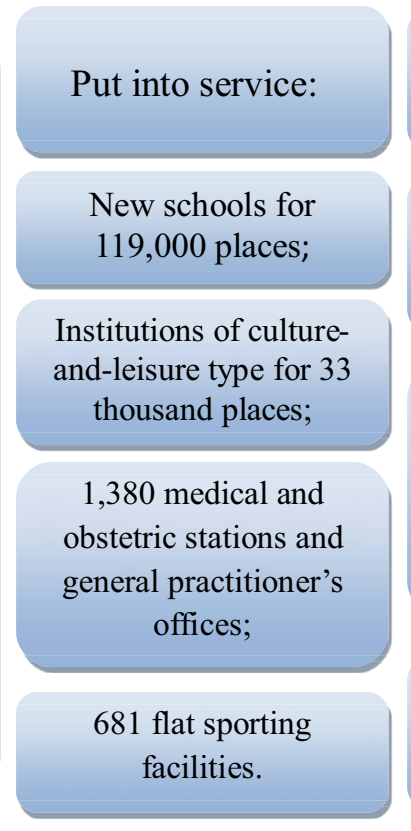

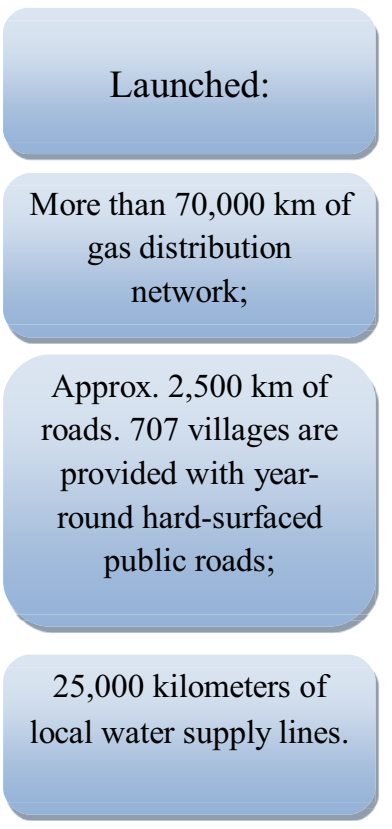

Fig. 2. Results of Federal Target Programs for Sustainable Rural Development for the period of 2003 2019

Thus, the sustainable development of rural areas must become the priority for the state development and the basis for the economic and social well-being of society.

\subsection{Concept of Demographic Policy for the Rostov Region}

The active state policy in the field of demography is being pursued in the Rostov Region, main goal of which is to create conditions for stabilization and subsequent growth in the region's population. Consequences of the demographic crisis of the 1990s continue to affect the current demographic situation, but the rate of population decline is slowing down from year to year [10]. 
The Demographic Policy Concept of the Rostov Region announces the following demographic policy objectives for the period until 2025:

- To stabilize the population and create conditions for its growth by 2025 ,

- To improve quality of life and increase life expectancy up to 75 years by 2025 .

Thereby, unfavourable demographic changes, i.e. permanent reduction in the population of rural settlements, shall also be taken into account.

\section{Conclusions}

Thus, establishment of clear boundaries of residential settlements in the Rostov Region will ensure availability of up-to-date information on the boundaries of settlements and territorial areas in the Unified State Register of Immovable Property and Public Database, which affects, inter alia, sustainable development of these areas, and will also contribute to improving land management procedures, their rational land-use planning, help resolve land disputes and increase the investment appeal of the region.

\section{References}

1. Immovable Property Cadastre, Cadastral activity in Russia: Experience of the present and prospects of the future, The 6th All-Russian Congress of Cadastral Engineers (SRO «Cadastral Engineers», Moscow, 2017)

2. M. Ogryzek, R.Wisniewski, T.Kauko, Real Estate Management and Valuation, 26(3) (2018) https://doi.org/10.2478/remav-2018-0022

3. N. Ovchinnikova, D. Burdova, M. Garanova, E3S Web of Conferences, 91 (2019) https://doi.org/10.1051/e3sconf/20199108023

4. T.S. Wilson, B.M. Sleeter, R.R. Sleeter, et al., Land, 3(2), (2014) https://doi.org/10.3390/land3020362

5. J. Wójcik-Leńa, K. S. Mikulska, N. Sajnóg, P. Leń, Land Use Policy, 78 (2018), https://doi.org/10.1016/j.landusepol.2018.06.044

6. W. Han, X. Zhang, X. Zheng, Land Use Policy, 92 (2020) https://doi.org/10.1016/j.landusepol.2019.104432

7. N.G. Ovchinnikova, MATEC Web of Conferences 10.1051/matecconf/201710601004

8. N.G. Ovchinnikova, Terra economicus, 7(2)-Cl.2, 41-44 (2009)

9. V.A. Chudovska, Balanced Nature Using, Institute of agroecology and environmental management, 7(4) (2016)

10. S. Lai, F. Leone, C. Zoppi, Sustainability, 9(12) (2017) https://doi.org/10.3390/su9122174

11. S.G.Sheina,.A.Khamavova, Procedia Engineering, 150 (2016) https://doi.org/10.1016/j.proeng.2016.07.198

12. O.Mertz, C. Filt Mertens, World Development, 98 (2017) https://doi.org/10.1016/j.worlddev.2017.05.002

13. M. Lengoiboni, C. Richter, Jaap Zevenbergen, Land Use Policy, 85 (2019) https://doi.org/10.1016/j.landusepol.2019.03.023

14. B. Gilbey, J. Davies, G. Metternicht, C. Magero, Environmental Science \& Policy, 100 (2019), https://doi.org/10.1016/j.envsci.2019.04.007

15. D. Smiraglia, T. Ceccarelli, S. Bajocco, L. Salvati, L. Perini, Environmental Research, 147 (2016), https://doi.org/10.1016/j.envres.2015.11.030 